\title{
Synthesis and evaluation of benzenesulfonic acid derivatives as human neutrophil elastase ( $\mathrm{hNE}$ ) inhibitors
}

\author{
Yanzhao $\mathrm{Xu}^{1} \cdot \mathrm{Na} \mathrm{Qi}^{1} \cdot$ Hui Wen ${ }^{1} \cdot$ Gang Zhang $^{1} \cdot$ Yuchen Wang ${ }^{1} \cdot$ Huaqing Cui $\circledast^{1}$ \\ Received: 25 October 2020 / Accepted: 2 December 2020 / Published online: 12 January 2021 \\ (c) The Author(s), under exclusive licence to Springer Science+Business Media, LLC part of Springer Nature 2021
}

\begin{abstract}
Herein we report our investigation concerning the development of Human neutrophil elastase (hNE) inhibitors for the treatment of Acute Respiratory Distress Syndrome (ARDS). Various benzenesulfonic acid derived compounds were synthesized and evaluated as competitive inhibitors of hNE. Biological screening revealed that compound $4 \mathbf{f}$ shows moderate inhibitory activity $\left(\mathrm{IC}_{50}=35.2 \mu \mathrm{M}\right)$ against hNE. Compound $\mathbf{4 f}$ was also superimposed onto the active center of $\mathrm{hNE}$ to understand the binding mode.
\end{abstract}

Keywords Human neutrophil elastase $\cdot$ Inhibitor $\cdot$ Benzenesulfonic acid $\cdot$ ARDS $\cdot$ Drug design

\section{Introduction}

Coronavirus Disease 2019 (COVID-19) is a pneumonia disease, which is caused by a virus called severe acute respiratory syndrome coronavirus 2 (SARS-CoV-2) [1]. Clinically, around $41.8 \%$ of severe COVID-19 patients will develop symptoms associated with acute respiratory distress syndrome (ARDS), such as, severe hypoxia and eventual respiratory failure [2]. Therefore, new treatments that treat the roots of severe hypoxia and respiratory failure should be addressed. Currently, mechanical ventilation is the most commonly used treatment for ARDS, while suppression of the strong immune response is a potential strategy to alleviate ARDS [3-5].

Human neutrophil elastase (hNE, EC 3.4.21.37) is a globular glycoprotein with a molecular weight of about

Supplementary information The online version of this article (https:// doi.org/10.1007/s00044-020-02684-4) contains supplementary material, which is available to authorized users.

Yuchen Wang

wangyuchen@imm.ac.cn

$\triangle$ Huaqing Cui

hcui@imm.ac.cn

1 State Key Laboratory of Bioactive Substances and Function of Natural Medicine, Institute of Materia Medica, Peking Union Medical College and Chinese Academy of Medical Sciences, 1 Xiannongtan Street, Beijing 100050, China
$30 \mathrm{kDa}[6,7] . \mathrm{hNE}$ is a serine proteinase and the proteolysis occurs through the Ser195-Asp102-His57 catalytic triad $[6,8,9]$. Elegant studies have shown that the proteolysis is triggered via His57, which in turn activates the hydroxyl group of Ser195. This nucleophilic hydroxyl group subsequently attached the carbonyl functionality of the target peptide bond and forms the classical tetrahedral intermediate. Subsequent proton transfers, mediated by His57, onto the amine of this tetrahedral intermediate results in a covalent acyl-enzyme complex. Finally, a water molecule attacks this complex to generate a new tetrahedral intermediate, which collapses and leads to the regeneration of activated hNE $[8,9]$.

$\mathrm{hNE}$ is an active proteinase and has been shown to degrade a range of proteins including all extracellular matrix proteins and many important plasma proteins $[6,10]$. Under normal physiological conditions, various immune cells use hNE as important protective species [6]. When the body undergoes inflammation or infection, neutrophils are the first called immune cells [11]. hNE and other proteases are secreted by neutrophils to destroy the pathogens and to regulate the inflammation. It was reported that every minute there was around 30 billion neutrophils distributed in lung capillaries, and each neutrophil can release up to $3 \mathrm{pg} \mathrm{hNE}$ $[6,12]$. Usually the activity of hNE was strictly controlled by endogenous inhibitors [13]. However, excessive secretion of hNE breaks the balance and further causes the overdegradation of the extracellular matrix in the inflammation site $[6,14]$. Furthermore, the increased damage of the lung and the continuous release of pro-inflammatory cytokines 
will result in an acute lung injury (ALI) [4], the early stage of ARDS [15]. hNE is known to contribute the production of mucin in airway epithelial cells [16]. Therefore, inhibition of hNE is considered to be one of the potential strategies to alleviate ARDS $[17,18]$.

Efforts have been made to discover potent and selective hNE inhibitors. Many naturally derived products have been reported exhibiting pronounced hNE inhibitory activity [19-21]. Laboratory designed hNE inhibitors fall into two key categories: peptides and heterocyclic compounds. Prolastin is a known peptide type hNE inhibitor, and has been shown to be successful in the treatment of $\alpha 1$-antitrypsin deficiency [22], however challenges remain bringing the treatment to market. Compared to peptides, heterocyclic compounds have many advantages, including metabolic stability, oral bioavailability, modularity in their synthesis, and more controlled ADME properties. Sivelestat (Fig. 1) is a selective and potent hNE inhibitor, which has been marketed in Japan and Korea for the treatment of ALI/ARDS related to systemic inflammatory response syndrome $[23,24]$. However, the performance of Sivelestat for the treatment of ALI/ARDS in the clinic remains controversial $[25,26]$. Therefore, it is necessary to develop additional safe and potent hNE small molecule inhibitors. At present, two potent and selective small molecule hNE inhibitors (Fig. 1) are in clinical trials: Alvelestat (AZD9668,
AstraZeneca, Cambridge, Germany) [27, 28] and Bay 858501 (Bayer HealthCare, Leverkusen, Germany) [29].

A series of benzenesulfonyl fluoride (SuEFx-1, Fig. 2) was previously reported as covalent inhibitors of $\mathrm{hNE}\left(\mathrm{IC}_{50}=\right.$ $3.3 \mu \mathrm{M})$ [30]. However the chemical instability and less than ideal hNE inhibitory profile of these benzenesulfonyl fluorides mean that further optimization is required (Fig. 2). Interestingly, due to the small size of SuEFx-1, the analogs can be used as the initial fragment for fragment based drug design. Further installment of additional effective fragments can lead to potent hNE inhibitors. Thus, taking advantage of the binding interaction between benzenesulfonyl fluoride and the target hNE enzyme, we utilized benzenesulfonic acids as a direct replacement to the benzenesulfonyl fluoride moiety with the aim to develop a competitive hNE inhibitor.

\section{Results and discussion}

\section{Design and synthesis of amide series}

Based on the structure of ortho-subtituted benzenesulfonyl fluoride (SuEFx-1), we designed a series of amide substituted benzenesulfonic acids $(\mathbf{4 a - h})$ including both orthoand meta- substituents. The synthesis of compounds $\mathbf{4 a - h}$ is described in Scheme 1. Acids chlorides, derived from the<smiles>CC(C)(C)C(=O)Oc1ccc(S(=O)(=O)Nc2ccccc2C(=O)NCC(=O)O[Na])cc1</smiles>

Sivelestat

$\mathrm{IC}_{50}=44 \mathrm{nM}$<smiles>Cc1c(-c2ccnn2C)cc(C(=O)NCc2ccc(S(C)(=O)=O)cn2)c(=O)n1-c1cccc(C(F)(F)F)c1</smiles>

Alvelestat

$\mathrm{IC}_{50}=12 \mathrm{nM}$<smiles>CC1=C(N)C(c2ccc(C#N)cc2S(C)(=O)=O)N(C)C(=O)N1c1cccc(C(F)(F)F)c1</smiles>

Bay 85-8501

$\mathrm{IC}_{50}=0.065 \mathrm{nM}$

Fig. 1 Current known hNE inhibitors

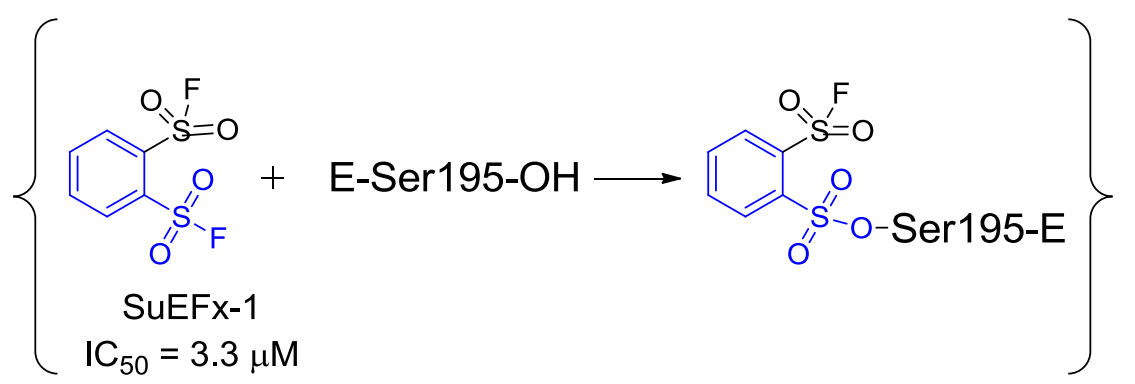

Covalent Inhibitor

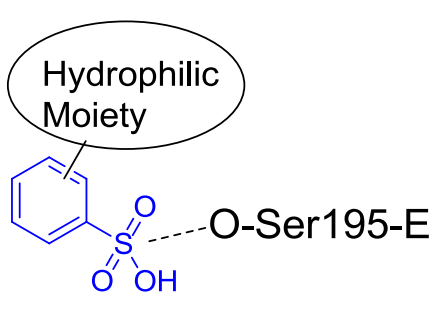

Competitive Inhibitor

Fig. 2 The mode of action of hNE covalent inhibitor, SuEFx-1[30]. hNE competitive inhibitors were also designed to mimic the transition state of covalent inhibitor, taking advantage of the binding mode of SuEFx-1 
reaction various carboxylic acids $(\mathbf{1 a}-\mathbf{h})$, with thionyl chloride were reacted with a range of sulfonic anilines $\mathbf{3}$ to give functionalized amide (4a-h) in synthetically useful yields.

Initially, we attempted to perform the condensation between compounds $(\mathbf{1 a}-\mathbf{h})$ and sulfonic aniline to directly obtain the desired amides, however this resulted in uniformly low yields. Then we decided to firstly transform the carboxylic acid into acyl chloride, the reaction between acyl chloride and the sulfonic acid substituted aniline will give the desired product. In order to prepare the acyl chloride, oxalyl chloride was firstly reacted with various carboxylic acid (1a-h). However, this protocol did not give a decent amount of acyl chloride. Then, we directly dissolved various carboxylic acid (1a-h) into thionyl chloride as the solvent and this protocol gave excellent transformation of acyl chloride. Due to DIPEA was used in the reaction as the organic base, the benzenesulfonic acid will form salt with
DIPEA. The solvent of DCM was removed from the reaction mixture and washed with the ether to quickly obtain the final products $\mathbf{4 c - f}$ and $\mathbf{4 h}$, which are DIPEA salts.

\section{Design and synthesis of urea series}

Next we designed a series of urea substituted benzenesulfonic acids (6a-j), which also includes both ortho- and meta- substituents. The compounds $(\mathbf{6} \mathbf{a}-\mathbf{j})$ were obtained by reacting various isocyanates $\mathbf{5 a}-\mathbf{j}$ with sulfonic aniline $\mathbf{3}$ (Scheme 2). All of the urea substituted benzenesulfonic acid $(\mathbf{6} \mathbf{a}-\mathbf{j})$ were purified as white solids with the yields above $80 \%$.

The urea was prepared with the reactants of the isocyanates and the amine. Various commercially available isocyanates reacted directly with sulfonic anilines to form the desired urea products. The reaction processed finely with decent yields. In addition, the final products were also existed as DIPEA salt. After the DCM was evaporated, the<smiles></smiles>
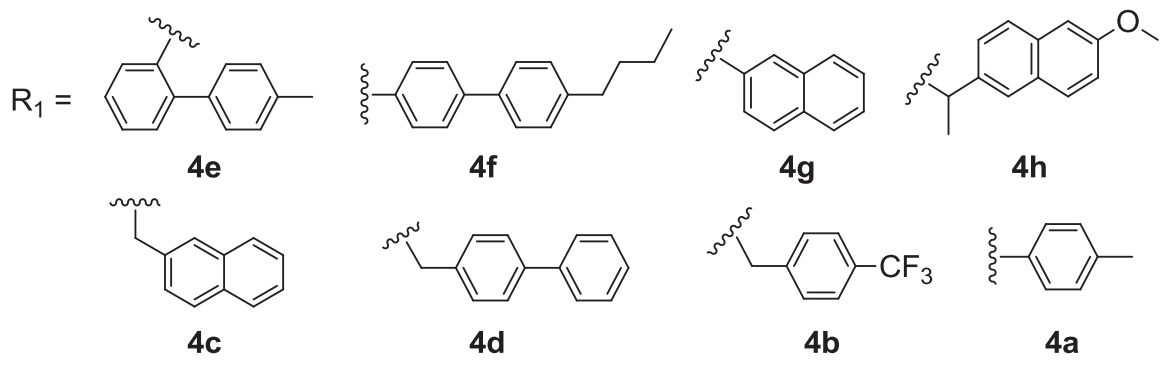

Scheme 1 Reaction conditions: $a, \mathrm{SOCl}_{2}, 2 \mathrm{~h} ; b$, anhydrous DCM, DIPEA, $4 \mathrm{~h}$

Scheme 2 Reaction conditions: $a$, anhydrous DCM, DIPEA, $8 \mathrm{~h}$

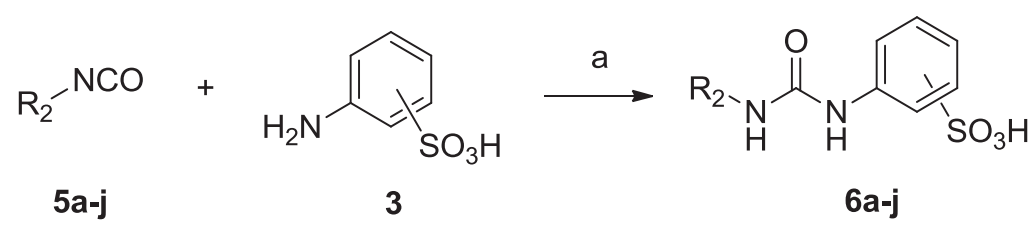

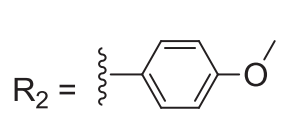

$6 a$<smiles>CC(C)c1cc(C(F)(F)F)cc(C(F)(F)F)c1</smiles>

6f<smiles>CC(C)c1ccc(Cl)cc1</smiles>

6b

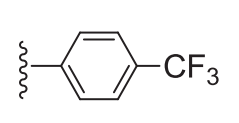

$6 c$

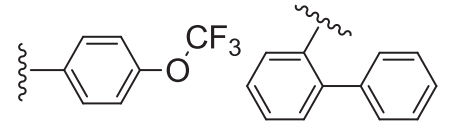

6d

$6 \mathbf{i}$<smiles>CC(C)(C)C(C)(C)C(=O)c1cc(Cl)cc(Cl)c1</smiles>

$6 \mathrm{e} / 6 \mathrm{~g}$<smiles>CCc1ccccc1</smiles>

6j 
Scheme 3 Reaction conditions: a, 1, 4-dioxane: $\mathrm{H}_{2} \mathrm{O}=4: 1$, $\mathrm{EtN}_{3}, \mathrm{Pd}(\mathrm{OAc})_{2}, 2 \mathrm{~h}$

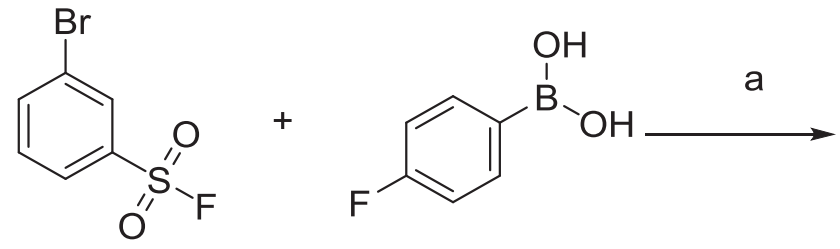

$7 a$ 7b<smiles>O=S(=O)(F)c1cccc(-c2ccc(F)cc2)c1</smiles>

$9 a$
Scheme 4 Reaction conditions: $a, \mathrm{SOCl}_{2}, 2 \mathrm{~h} ; b, \mathrm{KF}, 18$-crown6-ether, anhydrous $\mathrm{CH}_{3} \mathrm{CN}$, reflux, $\mathrm{Ar}, 12 \mathrm{~h}$

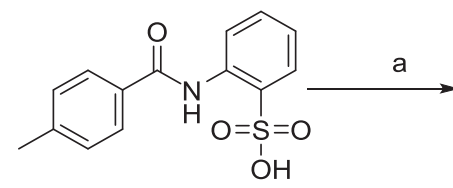

$4 a$

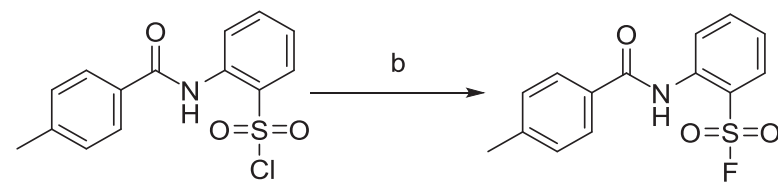

8

$9 b$ reaction mixture was washed with the ether to obtain the final product $\mathbf{6 a - j}$.

\section{Synthesis of benzenesulfonyl fluoride series}

We also designed and synthesized two benzenesulfonyl fluorides (9a, 9b) (Schemes 3 and 4). These two compounds contain the reactive group of sulfonyl fluoride, which can form covalent bond with the hydroxyl group of serine residue. 9a was synthesized via the Suzuki coupling of 7a and $\mathbf{7 b}$, while $\mathbf{9 b}$ was synthesized in two steps starting from the sulfonic acid $\mathbf{1 0}$.

In Scheme 3, Suzuki-Miyaura reaction was initially performed under the condition of $\mathrm{Pd}\left(\mathrm{PPh}_{3}\right)_{4}$, sodium carbonate at $100{ }^{\circ} \mathrm{C}$ under argon. However, we did not find the desired product under this condition. Then, we adopted relatively mild reaction conditions, we used palladium acetate as the catalyst, triethylamine as the base, and the reaction was carried out at room temperature under argon. Next, because the direct transformation of benzenesulfonic acid to benzenesulfonic fluorine is difficult, we first prepared the benzenesulfonyl chloride, which was then mixed with potassium fluoride and 18-crown-6 in anhydrous acetonitrile. The reaction needed to be refluxed. Moreover, in the process water was strictly eliminated to avoid hydrolysis of the final product benzenesulfonyl fluoride.

\section{In vitro hNE inhibitory activity}

Once we obtained our desired compounds, they were evaluated for hNE inhibitory activity (Table 1). In general, most of the compounds exhibited low hNE inhibitory activity, with the majority displaying inhibitory activity at very high concentrations $(100 \mu \mathrm{M})$. For the amide series $(\mathbf{4 a}-\mathbf{h})$, the substitution pattern of the amides (ortho- and meta-) showed no discernible difference in their activity against hNE.
However, we observed that the substituents attached to the amide had a clear impact on the hNE inhibitory activity. Most notable of these was the meta-amide-(4-biphenyl) substituted compound (4f), which exhibited decent potency against the target, with an $\mathrm{IC}_{50}$ of $35.2 \mu \mathrm{M}$. For the urea series $(\mathbf{6} \mathbf{a}-\mathbf{j})$, both ortho- and meta- ureas did not show significant difference in inhibitory activity against hNE. Interestingly, hydrophobic groups substituted at the para- or meta- positions of the phenyl ring were favorable, with clear inhibitory activity observed. The two benzenesulfonyl fluorides $(\mathbf{9 a}, 9 \mathbf{b})$, which we initially used as a direct comparison between covalent inhibitors and competitive inhibitors, showed no discernible inhibition profile against hNE.

It is worth noting that compounds $\mathbf{9 b}$ and $\mathbf{4 a}$ have similar structures with the only difference at sulfonyl acid or sulfonyl fluoride and both exhibited similar hNE activity. We therefore reason that the amide moiety plays an important role in hNE binding. Moreover, compound $\mathbf{4 f}$ containing the meta-amide moiety was discovered as the most potent hNE inhibitor. This emphasized the importance of the fragment of meta-amide-(4-biphenyl).

In addition, we also measured cell cytotoxicity of these compounds against five mammalian cancer cell lines, MCF-7, BGC823, A549, HepG2, and HCT116, and no obvious growth inhibition towards all five cell lines were observed for all the tested compounds at the concentration of $50 \mu \mathrm{M}$. This indicates that there is no inherent cell cytotoxicity for the core structure of benzenesulfonyl acids, and they can be further developed as the potential therapeutic agents of ARDS.

In summary, we evaluated 18 benzenesulfonyl acids and 2 benzenesulfonyl fluorides for their hNE inhibitory activities. Most of these compounds show low inhibition activities against hNE. We observed that our amide series exhibited slightly better inhibitory activities than the urea series. Compound $\mathbf{4 f}$ was the most active hNE inhibitor with the $\mathrm{IC}_{50}$ of $35.2 \mu \mathrm{M}$, and suggests that the amide-(4-biphenyl) 
Table 1 hNE inhibitory activity of compounds $\mathbf{4 ,} 6$, and 9

Compound

$4 a$

4b

$4 c$

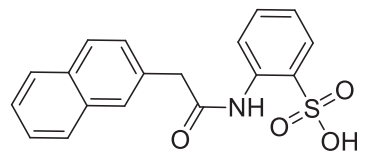

4d

$4 e$

4f
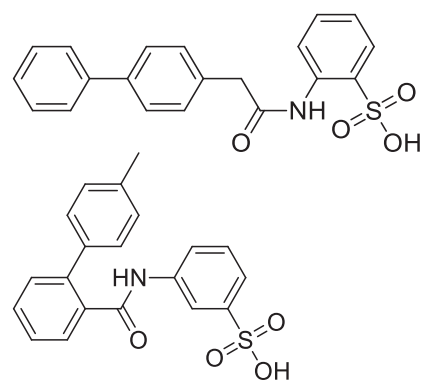

Structure
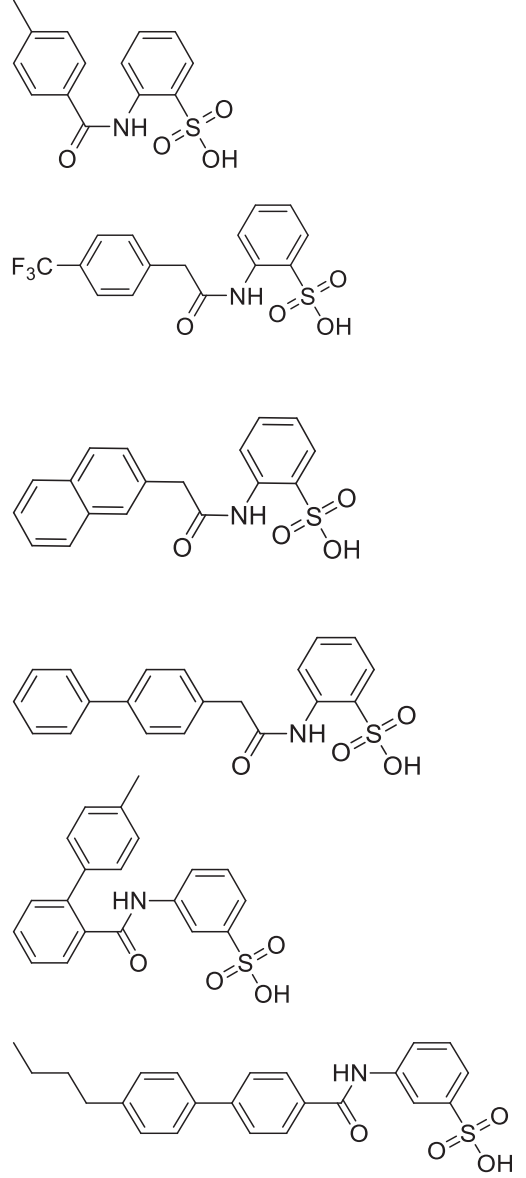

in

4h<smiles>COc1ccc2cc(C(C)C(=O)Nc3cccc(S(=O)(=O)O)c3)ccc2c1</smiles>

$6 a$<smiles>COc1ccc(NC(=O)Nc2ccccc2S(=O)(=O)O)cc1</smiles><smiles>O=C(Nc1ccc(Cl)cc1)Nc1ccccc1S(=O)(=O)O</smiles>

$21.8 \pm 5.2 \%$

0

Inhibition@100 $\mu \mathrm{M}$

$10.2 \pm 1.0 \%$

$10.3 \pm 4.9 \%$

$35.2 \mu \mathrm{M}\left(\mathrm{IC}_{50}\right)$

$21.1 \pm 2.3 \%$

$29.9 \pm 2.1 \%$

$19.4 \pm 2.2 \%$

$35.3 \pm 2.8 \%$ 
Table 1 (continued)

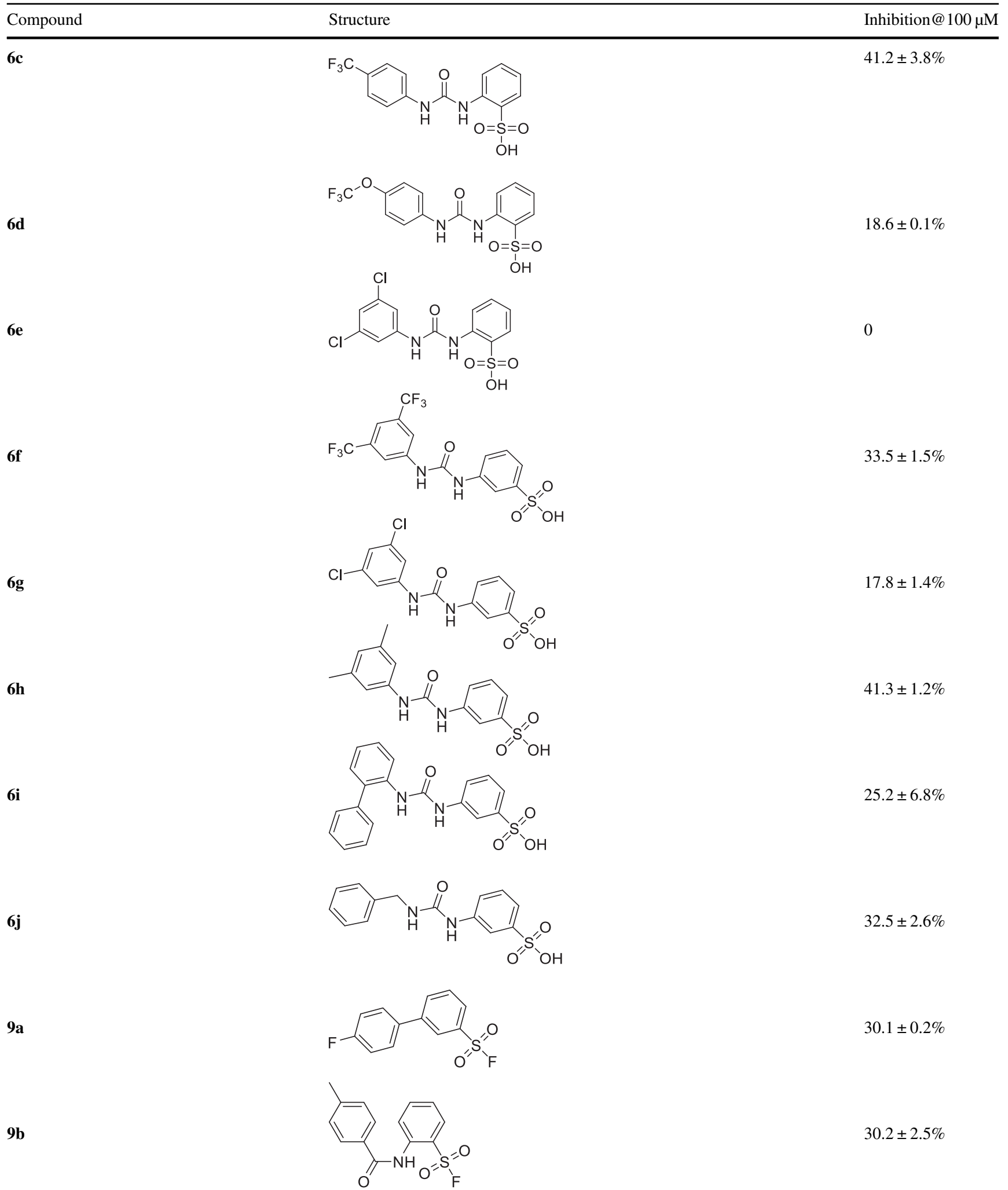


moiety in this scaffold plays a key role in providing hNE inhibitory activity.

\section{Molecular modeling}

Due to the performance of compound $\mathbf{4 f}$, and in order to ascertain key design principles, we decided to probe the key binding interaction with hNE with the hit compound. The experimental results showed that compound $\mathbf{4 f}$ occupied the same site as the original ligand SuEFx-1, benzene-1, 2disulfonyl fluoride, in the crystal structure 6e69 (Fig. 2A). Compound $4 \mathbf{f}$ formed key hydrogen bond interactions with His57, Ser214, and Val216. The phenyl ring of Phe192 had $\pi-$ $\pi$ stacking interaction with the middle phenyl ring of compound $\mathbf{4 f}$. The hydrophobic tail of compound $\mathbf{4 f}$ interacted with pocket formed by Leu35, Phe41, and Val62 (Fig. 2B, C).

Interestingly, the benzenesulfonic acid moiety of $\mathbf{4 f}$ exhibited similar binding mode as SuEFx-1. The residues of His57, Ser214, and Val216 interacted with the sulfonyl group in both compounds, while the covalent bond formed between Ser195 and the sulfonyl group of SuEFx-1 was not observed in the docking study of $\mathbf{4 f}$. Moreover, benzenesulfonic acid moiety is a relative small fragment, which cannot maintain a strong binding with hNE. Thus, the place of 4-diphenyl moiety in the right pocket of hNE further increases the overall inhibitory activity of the molecule.

\section{Conclusion}

In this work, starting from hNE covalent inhibitor SuEFx-1, we designed and synthesized two series of ortho- and metasubstituted benzenesulfonic acids and the inhibitory activities of these compounds were ascertained through in vitro experiments. The majority of these benzenesulfonic acids showed low inhibition against hNE, however $\mathbf{4 f}$ exhibited moderate hNE activity with an $\mathrm{IC}_{50}$ of $35.2 \mu \mathrm{M}$. We found that the substituents, particularly the amide-(4-diphenyl) moiety, of these compounds is important for the hNE inhibition. Computational docking revealed a similar binding position of compound $\mathbf{4 f}$ and SuEFx-1 in the active center of hNE, and also revealed the importance of the amide-4-diphenyl moiety for the binding. Taken together, we discovered a promising hit compound which can be further optimized to increase hNE inhibitory activity.

\section{Experimental section}

\section{Chemistry}

All solvents and chemicals were purchased from commercial sources: Sigma-Aldrich Chemical Co., Shanghai
Bepharm Science\&Technology Co., Shanghai Macklin Biotechnology Co., Tianjin Heowns Biotechnology Co., and Shanghai Jingke Chemistry Technology Co. with the purity of more than $95 \%$. Flash column chromatography was performed on a Biotage Isolera one. ${ }^{1} \mathrm{H}$ NMR, ${ }^{13} \mathrm{C}$ NMR, and ${ }^{19} \mathrm{~F}$ NMR were recorded on Mercury400, Bruker AVANCEIII 400 spectrometer. Chemical shifts are referenced to the residual solvent peak and reported in $\mathrm{ppm}(\delta$ scale) and all coupling constant $(J)$ values are given in Hertz $(\mathrm{Hz})$. The following multiplicity abbreviations are used: (s) singlet, (d) doublet, (t) triplet, (q) quartet, (m) multiplet. ESI-HRMS data were measured using a Thermo Exactive Orbitrap plus spectrometer. Purity was determined using LCMS. All of the synthesized compounds have a purity of $>95 \%$.

\section{General procedure for compounds $4 a-h$}

Carboxylic acid (1a-h) $(679.04 \mu \mathrm{mol})$ was dissolved in $\mathrm{SOCl}_{2}(2 \mathrm{~mL})$. The mixture was stirred at room temperature for $2 \mathrm{~h}$. After evaporation of the solvent, the intermediate (2a-h) was dissolved in anhydrous DCM $(2 \mathrm{~mL})$ and then added dropwise to another anhydrous DCM $(10 \mathrm{~mL})$ in which sulfonic aniline (3) $(565.87 \mu \mathrm{mol})$ and DIPEA $(188.94 \mu \mathrm{L})$ were dissolved. The mixture was stirred at room temperature for $4 \mathrm{~h}$ and the precipitate was recovered by vacuum filtration. The final compound was purified by column chromatography using methanol/dichloromethane $1: 19$ as eluents $(\mathbf{4 a}, \mathbf{4} \mathbf{b}$, and $\mathbf{4} \mathbf{g})$ or purified by stirring with the ether (4c-f and $\mathbf{4 h})$.

2-(4-methylbenzamido)benzenesulfonic acid (4a) Yield = $84 \%$; white solid. ${ }^{1} \mathrm{H}$ NMR $\left(400 \mathrm{MHz}, \mathrm{CD}_{3} \mathrm{OD}\right) \delta 8.51$ (dd, $J=8.3,2.0 \mathrm{~Hz}, 1 \mathrm{H}), 7.94-7.88(\mathrm{~m}, 3 \mathrm{H}), 7.52-7.43(\mathrm{~m}$, $1 \mathrm{H}), 7.34(\mathrm{~d}, J=8.0 \mathrm{~Hz}, 2 \mathrm{H}), 7.22-7.14(\mathrm{~m}, 1 \mathrm{H}), 2.42(\mathrm{~s}$, $3 \mathrm{H}) .{ }^{13} \mathrm{C}$ NMR (101 MHz, DMSO- $\left.d_{6}\right) \delta 164.48,142.49$, $135.83,135.76,132.39,130.30,129.87,127.53,127.44$, $122.99,120.13,21.52$. HRMS (ESI): $\mathrm{m} / \mathrm{z}$ calcd for $\mathrm{C}_{14} \mathrm{H}_{14} \mathrm{O}_{4} \mathrm{NS}[\mathrm{M}+\mathrm{H}]^{+}, 292.06381$; found, 292.06351.

2-(2-(4-(trifluoromethyl)phenyl)acetamido)benzenesulfonic acid (4b) Yield $=79 \%$; white solid. ${ }^{1} \mathrm{H}$ NMR $(400 \mathrm{MHz}$, DMSO- $\left.d_{6}\right) \delta 10.71(\mathrm{~s}, 1 \mathrm{H}), 8.23(\mathrm{~d}, J=8.0 \mathrm{~Hz}, 1 \mathrm{H}), 7.70$ (s, 1H), $7.67(\mathrm{~d}, J=7.6 \mathrm{~Hz}, 2 \mathrm{H}), 7.57(\mathrm{~d}, J=8.0 \mathrm{~Hz}, 2 \mathrm{H})$, $7.29(\mathrm{t}, J=7.9 \mathrm{~Hz}, 1 \mathrm{H}), 7.08-6.99(\mathrm{~m}, 1 \mathrm{H}), 3.77(\mathrm{~s}, 2 \mathrm{H})$. ${ }^{13} \mathrm{C}$ NMR (101 MHz, DMSO- $\left.d_{6}\right) \delta 168.24,140.63,135.89$, 135.42, 130.76, 130.11, 127.44, 125.64 (q, $J=3.8 \mathrm{~Hz}$ ), 123.03, 120.19, 44.57. HRMS (ESI): $\mathrm{m} / \mathrm{z}$ calcd for $\mathrm{C}_{15} \mathrm{H}_{13} \mathrm{O}_{4} \mathrm{NF}_{3} \mathrm{~S}[\mathrm{M}+\mathrm{H}]^{+}, 360.05119$; found, 360.05170 .

N-ethyl-N-isopropylpropan-2-aminium 2-(2-(naphthalen-2-yl) acetamido)benzenesulfonate (4c) Yield $=85 \%$; white solid. ${ }^{1} \mathrm{H}$ NMR (400 MHz, DMSO- $d_{6}$ ) $\delta 10.77$ (s, $1 \mathrm{H}$ ), 8.29 
$(\mathrm{d}, J=8.0 \mathrm{~Hz}, 1 \mathrm{H}), 8.15(\mathrm{~s}, 1 \mathrm{H}), 7.94-7.89(\mathrm{~m}, 2 \mathrm{H}), 7.88$ $(\mathrm{d}, J=4.7 \mathrm{~Hz}, 2 \mathrm{H}), 7.71(\mathrm{dd}, J=7.8,1.5 \mathrm{~Hz}, 1 \mathrm{H})$, $7.55-7.45(\mathrm{~m}, 3 \mathrm{H}), 7.34-7.27(\mathrm{~m}, 1 \mathrm{H}), 7.04(\mathrm{td}, J=7.7$, $1.0 \mathrm{~Hz}, 1 \mathrm{H}), 3.82(\mathrm{~s}, 2 \mathrm{H}), 3.54(\mathrm{p}, J=6.5 \mathrm{~Hz}, 2 \mathrm{H}), 3.06(\mathrm{q}$, $J=7.2 \mathrm{~Hz}, 2 \mathrm{H}), 1.19(\mathrm{t}, J=7.3 \mathrm{~Hz}, 15 \mathrm{H}),{ }^{13} \mathrm{C} \mathrm{NMR}$ $\left(101 \mathrm{MHz}, \mathrm{DMSO}-d_{6}\right) \delta 168.93,135.82,135.61,133.54$, $133.47,132.43,130.13,128.32,128.21,128.19,128.02$, $127.98,127.44,126.61,126.18,122.93,120.17,54.08$, 45.34, 42.33, 18.50, 17.13, 12.94.HRMS (ESI): $\mathrm{m} / \mathrm{z}$ calcd for $\mathrm{C}_{18} \mathrm{H}_{16} \mathrm{O}_{4} \mathrm{NS}[\mathrm{M}+\mathrm{H}]^{+}, 342.07946$; found, 342.07913 .

N-ethyl-N-isopropylpropan-2-aminium 2-(2-([1,1'-biphenyl]-4yl)acetamido)benzenesulfonate (4d) Yield $=75 \%$; white solid. ${ }^{1} \mathrm{H}$ NMR (400 MHz, DMSO- $\left.d_{6}\right) \delta 10.74(\mathrm{~s}, 1 \mathrm{H})$, 8.29-8.26 (m, 1H), 7.68 (dd, $J=8.4,1.3 \mathrm{~Hz}, 2 \mathrm{H}), 7.66-7.63$ $(\mathrm{m}, 2 \mathrm{H}), 7.62(\mathrm{~d}, J=1.8 \mathrm{~Hz}, 1 \mathrm{H}), 7.47(\mathrm{dd}, J=7.1,1.5 \mathrm{~Hz}$, $2 \mathrm{H}), 7.45-7.43(\mathrm{~m}, 2 \mathrm{H}), 7.38-7.33(\mathrm{~m}, 1 \mathrm{H}), 7.30(\mathrm{td}, J=8.5$, $8.1,1.6 \mathrm{~Hz}, 1 \mathrm{H}), 7.03(\mathrm{td}, J=7.6,1.2 \mathrm{~Hz}, 1 \mathrm{H}), 3.67(\mathrm{~s}, 2 \mathrm{H})$, $3.59(\mathrm{p}, J=6.5 \mathrm{~Hz}, 2 \mathrm{H}), 3.11(\mathrm{q}, J=7.3 \mathrm{~Hz}, 2 \mathrm{H}), 1.22(\mathrm{t}$, $J=7.5 \mathrm{~Hz}, 15 \mathrm{H}) .{ }^{13} \mathrm{C}$ NMR $\left(101 \mathrm{MHz}, \mathrm{DMSO}-d_{6}\right) \delta 168.86$, $140.41,139.09,135.80,135.58,135.08,130.32,130.07$, $129.39,127.80,127.42,127.16,127.05,122.85,120.00$, 54.01, 44.81, 42.28, 18.55, 17.20, 12.97. HRMS (ESI): $\mathrm{m} / \mathrm{z}$ calcd for $\mathrm{C}_{20} \mathrm{H}_{18} \mathrm{O}_{4} \mathrm{NS}[\mathrm{M}+\mathrm{H}]^{+}, 368.09511$; found, 368.09616 .

N-ethyl-N-isopropylpropan-2-aminium 3-(4'-methyl-[1,1'biphenyl]-2-carboxamido)benzenesulfonate (4e) Yield = 89\%; white solid. ${ }^{1} \mathrm{H}$ NMR (400 MHz, DMSO- $\left.d_{6}\right) \delta 10.27$ (s, 1H), 8.99 (s, 1H), $7.85(\mathrm{~s}, 1 \mathrm{H}), 7.52(\mathrm{t}, J=9.3 \mathrm{~Hz}, 3 \mathrm{H})$, $7.48-7.39$ (m, 2H), 7.34 (d, $J=7.7 \mathrm{~Hz}, 2 \mathrm{H}), 7.28$ (d, $J=$ $7.5 \mathrm{~Hz}, 1 \mathrm{H}), 7.24-7.12(\mathrm{~m}, 3 \mathrm{H}), 3.68-3.52$ (m, 2H), 3.12 $(\mathrm{dd}, J=6.9,4.6 \mathrm{~Hz}, 2 \mathrm{H}), 2.29$ (s, 3H), 1.27 (dd, $J=11.8$, $6.4 \mathrm{~Hz}, 15 \mathrm{H}) .{ }^{13} \mathrm{C}$ NMR (101 MHz, DMSO-d 6 ) $\delta 168.42$, $149.15,139.55,139.03,137.63,137.50,136.99,130.35$, $130.14,129.41,128.61,128.26,127.41,121.17,120.06$, 117.49, 53.75, 42.03, 21.16, 18.44, 17.17, 12.66. HRMS (ESI): $m / z$ calcd for $\mathrm{C}_{20} \mathrm{H}_{18} \mathrm{O}_{4} \mathrm{NS}[\mathrm{M}+\mathrm{H}]^{+}, 368.09511$; found, 368.09378.

N-ethyl-N-isopropylpropan-2-aminium 3-(4'-butyl-[1,1'biphenyl]-4-carboxamido)benzenesulfonate (4f) Yield = $77 \%$; white solid. ${ }^{1} \mathrm{H}$ NMR $\left(400 \mathrm{MHz}, \mathrm{DMSO}-d_{6}\right) \delta$ $10.33(\mathrm{~s}, 1 \mathrm{H}), 8.09(\mathrm{~s}, 1 \mathrm{H}), 8.07(\mathrm{~d}, J=2.3 \mathrm{~Hz}, 2 \mathrm{H})$, 7.89-7.84 (m, 1H), $7.81(\mathrm{~d}, J=8.4 \mathrm{~Hz}, 2 \mathrm{H}), 7.68$ (d, $J=$ $8.1 \mathrm{~Hz}, 2 \mathrm{H}), 7.37-7.29(\mathrm{~m}, 4 \mathrm{H}), 3.57(\mathrm{~s}, 1 \mathrm{H}), 3.08(\mathrm{~s}$, $1 \mathrm{H}), 2.64(\mathrm{t}, J=7.6 \mathrm{~Hz}, 2 \mathrm{H}), 1.60(\mathrm{p}, J=7.5 \mathrm{~Hz}, 2 \mathrm{H})$, $1.35(\mathrm{dt}, J=14.8,7.3 \mathrm{~Hz}, 2 \mathrm{H}), 1.28-1.15(\mathrm{~m}, 12 \mathrm{H}), 0.92$ $(\mathrm{t}, J=7.3 \mathrm{~Hz}, 3 \mathrm{H}) .{ }^{13} \mathrm{C}$ NMR $\left(101 \mathrm{MHz}, \mathrm{DMSO}-d_{6}\right) \delta$ $165.52,149.19,143.53,142.94,139.11,136.95,133.70$, $129.48,128.86,128.33,127.25,126.76,121.33,120.80$, $118.33,53.55,41.97,34.94,33.55,22.25,21.60,14.29$.
HRMS (ESI): $m / z$ calcd for $\mathrm{C}_{23} \mathrm{H}_{24} \mathrm{O}_{4} \mathrm{NS}[\mathrm{M}+\mathrm{H}]+$, 410.14206; found, 410.14246 .

3-(2-naphthamido)benzenesulfonic acid (4g) Yield =90\%; white solid. ${ }^{1} \mathrm{H}$ NMR (400 MHz, DMSO- $\left.d_{6}\right) \delta 13.08(\mathrm{~s}$, $1 \mathrm{H}), 8.61(\mathrm{~s}, 1 \mathrm{H}), 8.11(\mathrm{~d}, J=7.6 \mathrm{~Hz}, 2 \mathrm{H}), 8.08-8.04(\mathrm{~m}$, 1H), 8.03-7.97 (m, 4H), 7.67-7.58 (m, 3H), 7.41-7.30 (m, 1H). ${ }^{13} \mathrm{C}$ NMR (101 MHz, DMSO- $\left.d_{6}\right) \delta 167.93,139.13$, $135.41,134.76,132.63,131.00,129.76,129.47,128.81$, 128.65, 128.14, 127.29, 125.64, 124.99, 121.41, 120.76, 118.35. HRMS (ESI): $m / z$ calcd for $\mathrm{C}_{17} \mathrm{H}_{14} \mathrm{O}_{4} \mathrm{NS}[\mathrm{M}+\mathrm{H}]^{+}$, 328.06381; found, 328.06241 .

N-ethyl-N-isopropylpropan-2-aminium 3-(2-(6-methoxynaphthalen-2-yl)propanamido)benzenesulfonate (4h) Yield $=86 \%$; white solid. ${ }^{1} \mathrm{H}$ NMR (400 MHz, DMSO$\left.d_{6}\right) \delta 10.18(\mathrm{~s}, 1 \mathrm{H}), 7.86(\mathrm{~s}, 1 \mathrm{H}), 7.80(\mathrm{~d}, J=9.0 \mathrm{~Hz}, 2 \mathrm{H})$, $7.77(\mathrm{~d}, J=8.7 \mathrm{~Hz}, 1 \mathrm{H}), 7.68-7.62(\mathrm{~m}, 1 \mathrm{H}), 7.52(\mathrm{dd}, J$ $=8.5,1.6 \mathrm{~Hz}, 1 \mathrm{H}), 7.29-7.25(\mathrm{~m}, 2 \mathrm{H}), 7.22(\mathrm{t}, J=$ $7.7 \mathrm{~Hz}, 1 \mathrm{H}), 7.14(\mathrm{dd}, J=8.9,2.5 \mathrm{~Hz}, 1 \mathrm{H}), 3.97(\mathrm{q}, J=$ $6.9 \mathrm{~Hz}, 1 \mathrm{H}), 3.85(\mathrm{~s}, 3 \mathrm{H}), 3.55(\mathrm{dt}, J=12.5,5.9 \mathrm{~Hz}, 2 \mathrm{H})$, $3.07(\mathrm{q}, J=7.2,6.6 \mathrm{~Hz}, 2 \mathrm{H}), 1.49(\mathrm{~d}, J=7.0 \mathrm{~Hz}, 3 \mathrm{H})$, $1.21(\mathrm{t}, J=8.1 \mathrm{~Hz}, 15 \mathrm{H}) .{ }^{13} \mathrm{C}$ NMR $(101 \mathrm{MHz}, \mathrm{DMSO}-$ $\left.d_{6}\right) \delta 172.79,157.52,149.15,139.14,137.48,133.70$, $129.63,128.87,128.43,127.27,126.81,125.86,120.82$, $119.60,119.13,117.16,106.17,55.63,53.70,46.35$, 42.06, 21.63, 19.24, 13.06. HRMS (ESI): $\mathrm{m} / \mathrm{z}$ calcd for $\mathrm{C}_{20} \mathrm{H}_{20} \mathrm{O}_{5} \mathrm{NS}[\mathrm{M}+\mathrm{H}]^{+}, 386.10567$; found, 386.10602.

\section{General procedure for compounds $6 a-j$}

To a suspension of the sulfonic aniline (3) $(565.87 \mu \mathrm{mol})$ and DIPEA $(188.94 \mu \mathrm{L})$ in anhydrous DCM $(10 \mathrm{~mL})$, another anhydrous DCM (2 mL) with the appropriate commercially available isocyanate (5a-j) (679.04 $\mu \mathrm{mol})$ were added dropwise. The mixture was stirred at room temperature for $8 \mathrm{~h}$ and the precipitate was recovered by vacuum filtration. The final compound $\mathbf{6 a}-\mathbf{j}$ was purified by stirring with ether.

N-ethyl-N-isopropylpropan-2-aminium 2-(3-(4-methoxyphenyl) ureido)benzenesulfonate (6a) Yield $=84 \%$; white solid. ${ }^{1} \mathrm{H}$ NMR (400 MHz, DMSO-d $) \delta 9.40(\mathrm{~s}, 1 \mathrm{H}), 9.26(\mathrm{~s}, 1 \mathrm{H})$, $7.99(\mathrm{~d}, J=8.1 \mathrm{~Hz}, 1 \mathrm{H}), 7.64(\mathrm{~d}, J=7.9 \mathrm{~Hz}, 1 \mathrm{H}), 7.43$ (d, $J=8.9 \mathrm{~Hz}, 2 \mathrm{H}), 7.24(\mathrm{t}, J=7.6 \mathrm{~Hz}, 1 \mathrm{H}), 6.91(\mathrm{t}, J=7.5 \mathrm{~Hz}$, $1 \mathrm{H}), 6.84(\mathrm{~d}, J=8.9 \mathrm{~Hz}, 2 \mathrm{H}), 3.71(\mathrm{~s}, 3 \mathrm{H}), 3.65-3.56(\mathrm{~m}$, 2H), 3.18-3.07 (m, 2H), $1.25(\mathrm{t}, J=6.1 \mathrm{~Hz}, 15 \mathrm{H}) .{ }^{13} \mathrm{C} \mathrm{NMR}$ $\left(101 \mathrm{MHz}, \mathrm{DMSO}-d_{6}\right) \delta 154.72,153.08,136.78,135.59$, $133.78,129.59,127.20,121.10,121.00,120.72,114.23$, 55.59, 54.07, 42.32, 18.54, 17.19, 12.96. HRMS (ESI): $\mathrm{m} / \mathrm{z}$ calcd for $\mathrm{C}_{14} \mathrm{H}_{15} \mathrm{O}_{5} \mathrm{~N}_{2} \mathrm{~S}[\mathrm{M}+\mathrm{H}]^{+}, 323.06962$; found, 323.06921 . 
N-ethyl-N-isopropylpropan-2-aminium 2-(3-(4-chlorophenyl) ureido)benzenesulfonate (6b) Yield $=89 \%$; white solid. ${ }^{1} \mathrm{H}$ NMR (400 MHz, DMSO-d $d_{6} \delta 9.76(\mathrm{~s}, 1 \mathrm{H}), 9.37(\mathrm{~s}, 1 \mathrm{H})$, $8.18(\mathrm{~s}, 1 \mathrm{H}), 7.97(\mathrm{~d}, J=8.1 \mathrm{~Hz}, 1 \mathrm{H}), 7.65$ (dd, $J=7.7$, $1.2 \mathrm{~Hz}, 1 \mathrm{H}), 7.57(\mathrm{~d}, J=8.9 \mathrm{~Hz}, 2 \mathrm{H}), 7.30(\mathrm{~d}, J=8.9 \mathrm{~Hz}$, 2H), 7.28-7.24 (m, 1H), $6.95(\mathrm{t}, J=7.5 \mathrm{~Hz}, 1 \mathrm{H}), 3.61$ (ddp, $J=10.3,6.4,3.8 \mathrm{~Hz}, 2 \mathrm{H}), 3.13(\mathrm{qd}, J=7.3,4.5 \mathrm{~Hz}, 2 \mathrm{H})$, $1.25(\mathrm{t}, J=6.1 \mathrm{~Hz}, 15 \mathrm{H}) .{ }^{13} \mathrm{C}$ NMR $\left(101 \mathrm{MHz}, \mathrm{DMSO}-d_{6}\right)$ $\delta 152.83,139.78,136.34,135.88,129.65,128.87,127.22$, 125.55, 121.44, 121.27, 120.43, 54.07, 42.32, 18.55, 17.19, 12.96. HRMS (ESI): $m / z$ calcd for $\mathrm{C}_{13} \mathrm{H}_{12} \mathrm{O}_{4} \mathrm{~N}_{2} \mathrm{ClS}[\mathrm{M}+\mathrm{H}]^{+}$, 327.02008; found, 327.01978.

N-ethyl-N-isopropylpropan-2-aminium 2-(3-(4-(trifluoromethyl) phenyl)ureido)benzenesulfonate (6c) Yield $=85 \%$; white solid. ${ }^{1} \mathrm{H}$ NMR (400 MHz, DMSO-d $) ~ \delta 10.06$ (s, 1H), 9.46 $(\mathrm{s}, 1 \mathrm{H}), 8.18(\mathrm{~s}, 1 \mathrm{H}), 7.98(\mathrm{~d}, J=7.6 \mathrm{~Hz}, 1 \mathrm{H}), 7.75(\mathrm{~d}, J=$ $8.6 \mathrm{~Hz}, 2 \mathrm{H}), 7.67(\mathrm{dd}, J=7.7,1.5 \mathrm{~Hz}, 1 \mathrm{H}), 7.61$ (d, $J=$ $8.7 \mathrm{~Hz}, 2 \mathrm{H}), 7.31-7.25(\mathrm{~m}, 1 \mathrm{H}), 7.02-6.92(\mathrm{~m}, 1 \mathrm{H}), 3.60$ (dp, $J=10.5,3.9 \mathrm{~Hz}, 2 \mathrm{H}), 3.13(\mathrm{dq}, J=7.3,3.0 \mathrm{~Hz}, 2 \mathrm{H}), 1.25(\mathrm{t}$, $J=6.2 \mathrm{~Hz}, 15 \mathrm{H}) .{ }^{13} \mathrm{C} \mathrm{NMR}\left(101 \mathrm{MHz}, \mathrm{DMSO}-d_{6}\right) \delta 152.76$, 145.57, 144.56, 136.12, $129.86(\mathrm{~d}, J=27.6 \mathrm{~Hz}), 127.47$ (d, $J=44.7 \mathrm{~Hz}), 126.35(\mathrm{~d}, J=3.8 \mathrm{~Hz}), 123.77,121.98(\mathrm{~d}, J=$ $31.7 \mathrm{~Hz}), 121.60(\mathrm{~d}, J=30.2 \mathrm{~Hz}), 118.55,115.83,114.77$, 54.08, 42.34, 18.53, 17.17, 12.94. HRMS (ESI): $\mathrm{m} / \mathrm{z}$ calcd for $\mathrm{C}_{14} \mathrm{H}_{12} \mathrm{O}_{4} \mathrm{~N}_{2} \mathrm{~F}_{3} \mathrm{~S} \quad[\mathrm{M}+\mathrm{H}]^{+}, \quad 361.04644$; found, 361.04568 .

N-ethyl-N-isopropylpropan-2-aminium 2-(3-(4-(trifluoromethoxy) phenyl)ureido)benzenesulfonate (6d) Yield $=91 \%$; white solid. ${ }^{1} \mathrm{H}$ NMR (400 MHz, DMSO- $\left.d_{6}\right) \delta 9.83$ (s, 1H), 9.40 (s, $1 \mathrm{H}), 8.55$ (s, 1H), $7.99(\mathrm{~d}, J=8.2 \mathrm{~Hz}, 1 \mathrm{H}), 7.67$ (d, $J=$ $1.5 \mathrm{~Hz}, 1 \mathrm{H}), 7.66-7.61(\mathrm{~m}, 2 \mathrm{H}), 7.29$ (d, $J=1.5 \mathrm{~Hz}, 1 \mathrm{H}), 7.25$ $(\mathrm{s}, 2 \mathrm{H}), 6.95(\mathrm{t}, J=7.5 \mathrm{~Hz}, 1 \mathrm{H}), 3.60(\mathrm{td}, J=6.6,3.9 \mathrm{~Hz}, 2 \mathrm{H})$, 3.14-3.08 (m, 2H), 1.26-1.23 (m, 15H). ${ }^{13} \mathrm{C} \mathrm{NMR} \mathrm{(101} \mathrm{MHz,}$ DMSO- $\left.d_{6}\right) \delta 152.88,142.90(\mathrm{~d}, J=1.6 \mathrm{~Hz}), 140.07,136.34$, $135.86,129.67,128.82(\mathrm{~d}, J=224.2 \mathrm{~Hz}), 127.24,121.96$, 121.47, 121.23, 120.08, 53.98, 42.24, 18.51, 17.18, 12.87. HRMS (ESI): $m / z$ calcd for $\mathrm{C}_{14} \mathrm{H}_{12} \mathrm{O}_{5} \mathrm{~N}_{2} \mathrm{~F}_{3} \mathrm{~S}[\mathrm{M}+\mathrm{H}]^{+}$, 377.04135; found, 377.04102.

\section{$\mathrm{N}$-ethyl-N-isopropylpropan-2-aminium 2-(3-(3,5-dichlorophe-} nyl)ureido)benzenesulfonate (6e) Yield $=85 \%$; white solid. ${ }^{1} \mathrm{H}$ NMR (400 MHz, DMSO- $\left.d_{6}\right) \delta 9.98$ (s, 1H), 9.47 $(\mathrm{s}, 1 \mathrm{H}), 8.20(\mathrm{~s}, 1 \mathrm{H}), 8.04-7.90(\mathrm{~m}, 2 \mathrm{H}), 7.68(\mathrm{~d}, J=$ $7.5 \mathrm{~Hz}, 1 \mathrm{H}), 7.48$ (q, $J=8.7 \mathrm{~Hz}, 2 \mathrm{H}), 7.29$ (t, $J=7.4 \mathrm{~Hz}$, $1 \mathrm{H}), 6.98(\mathrm{t}, J=7.3 \mathrm{~Hz}, 1 \mathrm{H}), 3.67-3.50(\mathrm{~m}, 2 \mathrm{H}), 3.17-3.02$ $(\mathrm{m}, 2 \mathrm{H}), 1.23(\mathrm{t}, J=6.1 \mathrm{~Hz}, 15 \mathrm{H}) .{ }^{13} \mathrm{C} \mathrm{NMR}(101 \mathrm{MHz}$, DMSO- $\left.d_{6}\right) \delta 152.69,141.04,136.07,135.93,131.30$, $130.91,129.76,127.25,123.31,121.75,121.30,119.89$, 118.91, 54.07, 42.33, 18.52, 17.16, 12.93. HRMS (ESI): $\mathrm{m} /$ $z$ calcd for $\mathrm{C}_{13} \mathrm{H}_{11} \mathrm{O}_{4} \mathrm{~N}_{2} \mathrm{Cl}_{2} \mathrm{~S}[\mathrm{M}+\mathrm{H}]^{+}, 360.98111$; found, 360.98172 .
N-ethyl-N-isopropylpropan-2-aminium 3-(3-(3,5-bis(trifluoromethyl)phenyl)ureido)benzenesulfonate (6f) Yield $=90 \%$; white solid. ${ }^{1} \mathrm{H}$ NMR (400 MHz, DMSO- $\left.d_{6}\right) \delta 9.49(\mathrm{~s}, 1 \mathrm{H})$, $9.24(\mathrm{~s}, 1 \mathrm{H}), 8.16(\mathrm{~s}, 2 \mathrm{H}), 7.81-7.76(\mathrm{~m}, 1 \mathrm{H}), 7.62(\mathrm{~s}, 1 \mathrm{H})$, $7.57(\mathrm{dt}, J=6.5,2.4 \mathrm{~Hz}, 1 \mathrm{H}), 7.30-7.24(\mathrm{~m}, 2 \mathrm{H}), 3.61(\mathrm{pd}$, $J=6.6,3.9 \mathrm{~Hz}, 2 \mathrm{H}), 3.13(\mathrm{qd}, J=7.3,4.3 \mathrm{~Hz}, 2 \mathrm{H}), 1.25(\mathrm{t}$, $J=6.3 \mathrm{~Hz}, 15 \mathrm{H}) .{ }^{13} \mathrm{C}$ NMR $\left(101 \mathrm{MHz}\right.$, DMSO- $\left.d_{6}\right) \quad \delta$ $152.84,148.74,142.45,139.16,131.50(\mathrm{~d}, J=32.5 \mathrm{~Hz})$, $130.85(\mathrm{~d}, J=32.5 \mathrm{~Hz}), 128.80,125.17,122.45,120.11$, 119.30, 118.29, 116.45, 54.02, 42.28, 18.54, 17.20, 12.94. HRMS (ESI): $m / z$ calcd for $\mathrm{C}_{15} \mathrm{H}_{11} \mathrm{O}_{4} \mathrm{~N}_{2} \mathrm{~F}_{6} \mathrm{~S}[\mathrm{M}+\mathrm{H}]^{+}$, 429.03382; found, 429.03354 .

N-ethyl-N-isopropylpropan-2-aminium 3-(3-(3,5-dichlorophenyl)ureido)benzenesulfonate $\quad(6 \mathrm{~g})$ Yield $=82 \%$; white solid. ${ }^{1} \mathrm{H}$ NMR (400 MHz, DMSO- $\left.d_{6}\right) \delta 9.04(\mathrm{~s}, 1 \mathrm{H}), 9.01$ $(\mathrm{s}, 1 \mathrm{H}), 7.93-7.84(\mathrm{~m}, 1 \mathrm{H}), 7.75-7.68(\mathrm{~m}, 1 \mathrm{H}), 7.52(\mathrm{dd}$, $J=9.0,5.6 \mathrm{~Hz}, 2 \mathrm{H}), 7.36(\mathrm{dd}, J=8.8,2.5 \mathrm{~Hz}, 1 \mathrm{H}), 7.25(\mathrm{~d}$, $J=5.0 \mathrm{~Hz}, 2 \mathrm{H}), 3.61(\mathrm{pd}, J=6.6,4.0 \mathrm{~Hz}, 2 \mathrm{H}), 3.13(\mathrm{qd}$, $J=7.4,4.3 \mathrm{~Hz}, 2 \mathrm{H}), 1.24(\mathrm{q}, J=6.7 \mathrm{~Hz}, 15 \mathrm{H}) .{ }^{13} \mathrm{C} \mathrm{NMR}$ $\left(101 \mathrm{MHz}, \mathrm{DMSO}-\mathrm{d}_{6}\right) \delta 152.78,148.71,140.60,139.42$, $131.47,131.04,128.76,123.44,119.83,119.61,118.95$, 118.69, 116.14, 53.95, 42.20, 18.59, 17.25, 13.00. HRMS (ESI): $m / z$ calcd for $\mathrm{C}_{13} \mathrm{H}_{11} \mathrm{O}_{4} \mathrm{~N}_{2} \mathrm{Cl}_{2} \mathrm{~S} \quad[\mathrm{M}+\mathrm{H}]^{+}$, 360.98111; found, 360.98083 .

N-ethyl-N-isopropylpropan-2-aminium 3-(3-(3,5-dimethylphenyl)ureido)benzenesulfonate (6h) Yield $=80 \%$; white solid. ${ }^{1} \mathrm{H}$ NMR (400 MHz, DMSO- $\left.d_{6}\right) \delta 8.57$ (s, 1H), 7.07 $(\mathrm{s}, 2 \mathrm{H}), 6.97-6.91(\mathrm{~m}, 1 \mathrm{H}), 6.91-6.87(\mathrm{~m}, 1 \mathrm{H}), 6.79-6.72$ $(\mathrm{m}, 1 \mathrm{H}), 6.59(\mathrm{~s}, 1 \mathrm{H}), 6.51-6.44(\mathrm{~m}, 1 \mathrm{H}), 3.61(\mathrm{dq}, J=$ $13.1,6.5 \mathrm{~Hz}, 2 \mathrm{H}), 3.12(\mathrm{dt}, J=11.0,5.4 \mathrm{~Hz}, 2 \mathrm{H}), 2.22(\mathrm{~s}$, $6 \mathrm{H}), 1.25(\mathrm{t}, J=6.3 \mathrm{~Hz}, 15 \mathrm{H}) .{ }^{13} \mathrm{C} \mathrm{NMR}(101 \mathrm{MHz}$, DMSO- $\left.d_{6}\right) \delta 152.95,149.90,140.14,138.12,137.05$, $129.45,123.77,121.86,120.71,118.08,116.29,54.06$, 42.31, 21.62, 18.55, 17.21, 12.94. HRMS (ESI): $\mathrm{m} / \mathrm{z}$ calcd for $\mathrm{C}_{15} \mathrm{H}_{17} \mathrm{O}_{4} \mathrm{~N}_{2} \mathrm{~S} \quad[\mathrm{M}+\mathrm{H}]^{+}, \quad 321.09035$; found, 321.09039 .

N-ethyl-N-isopropylpropan-2-aminium 3-(3-([1,1'-biphenyl]2-yl)ureido)benzenesulfonate (6i) Yield $=84 \%$; white solid. ${ }^{1} \mathrm{H}$ NMR (400 MHz, DMSO- $d_{6}$ ) $\delta 9.09$ (s, 1H), 8.21 (s, 1H), $7.94(\mathrm{~d}, J=8.2 \mathrm{~Hz}, 1 \mathrm{H}), 7.60(\mathrm{~s}, 1 \mathrm{H}), 7.57(\mathrm{~s}, 1 \mathrm{H})$, $7.52(\mathrm{t}, J=7.4 \mathrm{~Hz}, 2 \mathrm{H}), 7.42(\mathrm{t}, J=8.2 \mathrm{~Hz}, 4 \mathrm{H}), 7.37-7.30$ $(\mathrm{m}, 1 \mathrm{H}), 7.23-7.19(\mathrm{~m}, 1 \mathrm{H}), 7.18(\mathrm{~s}, 1 \mathrm{H}), 7.16-7.09(\mathrm{~m}$, $1 \mathrm{H}), 3.61(\mathrm{dq}, J=6.7,4.2 \mathrm{~Hz}, 2 \mathrm{H}), 3.14(\mathrm{dd}, J=7.3$, $4.2 \mathrm{~Hz}, 2 \mathrm{H}), \quad 1.25(\mathrm{~d}, \quad J=6.2 \mathrm{~Hz}, 15 \mathrm{H}) .{ }^{13} \mathrm{C} \quad \mathrm{NMR}$ $\left(101 \mathrm{MHz}, \mathrm{DMSO}-d_{6}\right) \delta 153.14,149.30,139.68,138.92$, $136.17,133.15,130.76,129.63,129.34,128.55,127.99$, $123.74,123.10,119.42,118.27,115.84,114.31,113.64$, 111.93, 54.07, 42.33, 18.54, 17.19, 12.94. HRMS (ESI): $\mathrm{m} /$ $z$ calcd for $\mathrm{C}_{19} \mathrm{H}_{17} \mathrm{O}_{4} \mathrm{~N}_{2} \mathrm{~S}[\mathrm{M}+\mathrm{H}]^{+}, 369.09035$; found, 369.08954 . 
N-ethyl-N-isopropylpropan-2-aminium 3-(3-benzylureido)benzenesulfonate (6j) Yield $=90 \%$; white solid. ${ }^{1} \mathrm{H}$ NMR $\left(400 \mathrm{MHz}, \mathrm{DMSO}-d_{6}\right) \delta 8.62(\mathrm{~s}, 1 \mathrm{H}), 8.20(\mathrm{~s}, 1 \mathrm{H}), 7.60(\mathrm{~s}$, $1 \mathrm{H}), 7.44(\mathrm{~d}, J=7.3 \mathrm{~Hz}, 1 \mathrm{H}), 7.32(\mathrm{~d}, J=6.5 \mathrm{~Hz}, 4 \mathrm{H}), 7.23$ $(\mathrm{t}, J=6.6 \mathrm{~Hz}, 1 \mathrm{H}), 7.15(\mathrm{q}, J=7.2 \mathrm{~Hz}, 2 \mathrm{H}), 6.58(\mathrm{t}, J=$ $5.7 \mathrm{~Hz}, 1 \mathrm{H}), 4.34-4.25(\mathrm{~m}, 2 \mathrm{H}), 3.61(\mathrm{dd}, J=10.1,6.2 \mathrm{~Hz}$, $2 \mathrm{H}), 3.16-3.10(\mathrm{~m}, 2 \mathrm{H}), 1.24(\mathrm{~d}, J=6.2 \mathrm{~Hz}, 15 \mathrm{H}) .{ }^{13} \mathrm{C} \mathrm{NMR}$ $\left(101 \mathrm{MHz}, \mathrm{DMSO}-d_{6}\right) \delta 155.64,149.15,140.85,140.35$, 128.76, 128.35, 127.59, 127.15, 118.09, 115.57, 54.07, 43.19, 42.33, 18.54, 17.19, 12.95. HRMS (ESI): $\mathrm{m} / \mathrm{z}$ calcd for $\mathrm{C}_{14} \mathrm{H}_{15} \mathrm{O}_{4} \mathrm{~N}_{2} \mathrm{~S}[\mathrm{M}+\mathrm{H}]^{+}$, 307.07470; found, 307.07449.

\section{General procedure for compound 9a}

The starting materials 7a $(418.31 \mu \mathrm{mol}), 7 \mathbf{b}(627.46 \mu \mathrm{mol})$, $\mathrm{EtN}_{3}(175.48 \mu \mathrm{L})$ and $\mathrm{Pd}(\mathrm{OAc})_{2}(4.18 \mu \mathrm{mol})$ were sequentially added to the solvent (1,4-dioxane: $\mathrm{H}_{2} \mathrm{O}=4: 1$ ) $(10 \mathrm{~mL})$. The mixture was stirred at room temperature for $2 \mathrm{~h}$. After the solvent was evaporated in vacuo, ethyl acetate was added, and washed with $1 \mathrm{~N}$ dilute hydrochloric acid $(15 \mathrm{~mL})$ and saturated brine $(3 \times 15 \mathrm{~mL})$ successively. The organic layer was dried with anhydrous $\mathrm{Na}_{2} \mathrm{SO}_{4}$. The final compound 9a was purified by column chromatography using ethyl acetate/petroleum ether 1:19 as the eluent.

4'-fluoro-[1,1'-biphenyl]-3-sulfonyl fluoride (9a) Yield = $34 \%$; white solid. ${ }^{1} \mathrm{H}$ NMR (400 MHz, $\left.\mathrm{CDCl}_{3}\right) \delta 8.22$ (t, $J=$ $1.8 \mathrm{~Hz}, 1 \mathrm{H}), 8.06(\mathrm{~d}, J=7.9 \mathrm{~Hz}, 1 \mathrm{H}), 7.99$ (d, $J=7.9 \mathrm{~Hz}$, $1 \mathrm{H}), 7.78(\mathrm{~d}, J=1.8 \mathrm{~Hz}, 1 \mathrm{H}), 7.76(\mathrm{~s}, 2 \mathrm{H}), 7.72$ (d, $J=$ $8.4 \mathrm{~Hz}, 2 \mathrm{H}) .{ }^{13} \mathrm{C}$ NMR $\left(101 \mathrm{MHz}, \mathrm{CDCl}_{3}\right) \delta 163.24(\mathrm{~d}, J=$ $249.0 \mathrm{~Hz}), 142.22$, 134.66-133.52 (m), 133.90, 130.21, $128.97(\mathrm{~d}, J=8.1 \mathrm{~Hz}), 126.87,126.66,116.28(\mathrm{~d}, J=$ $21.5 \mathrm{~Hz}) .{ }^{19} \mathrm{~F}$ NMR $\left(376 \mathrm{MHz}, \mathrm{CDCl}_{3}\right) \delta 66.07,-112.89$. HRMS (ESI): $m / z$ calcd for $\mathrm{C}_{12} \mathrm{H}_{8} \mathrm{O}_{2} \mathrm{~F}_{2} \mathrm{~S} \quad[\mathrm{M}+\mathrm{H}]^{+}$, 255.02858; found, 255.02861.

\section{General procedure for compound 9b}

Benzenesulfonic acid (4a) (171.63 $\mu \mathrm{mol})$ was dissolved in $\mathrm{SOCl}_{2}(2 \mathrm{~mL})$. The mixture was stirred at room temperature for $2 \mathrm{~h}$. After evaporation of the solvent, the intermediate (8) was dissolved in anhydrous $\mathrm{CH}_{3} \mathrm{CN}(10 \mathrm{~mL})$ in which $\mathrm{KF}(3.23 \mathrm{mmoL})$ and 18 -crown-6-ether $(8.07 \mu \mathrm{moL})$ were dissolved. The mixture was stirred at reflux for $12 \mathrm{~h}$ in an argon-filled environment. After the solvent was evaporated in vacuo, ethyl acetate was added, and washed with saturated brine $(3 \times 15 \mathrm{~mL})$. The organic layer was dried with anhydrous $\mathrm{Na}_{2} \mathrm{SO}_{4}$. The final compound $9 \mathbf{a}$ was purified by column chromatography using ethyl acetate/petroleum ether $1: 9$ as the eluent.

2-(4-methylbenzamido)benzenesulfonyl fluoride (9b) Yield = $26 \%$; yellow flaky solid. ${ }^{1} \mathrm{H} \mathrm{NMR}\left(400 \mathrm{MHz}, \mathrm{CDCl}_{3}\right) \delta 9.75$ (s, 1H), 8.92-8.82 (m, 1H), 8.08-8.00 (m, 1H), $7.85(\mathrm{~d}, J=$ $8.2 \mathrm{~Hz}, 2 \mathrm{H}), 7.81(\mathrm{t}, J=7.4 \mathrm{~Hz}, 1 \mathrm{H}), 7.34(\mathrm{~d}, J=8.0 \mathrm{~Hz}$, 2H), $7.31(\mathrm{~d}, J=8.0 \mathrm{~Hz}, 1 \mathrm{H}), 2.45(\mathrm{~s}, 3 \mathrm{H}) .{ }^{13} \mathrm{C} \mathrm{NMR}$ $\left(101 \mathrm{MHz}, \mathrm{DMSO}-d_{6}\right) \delta 166.48,142.81,137.72,137.56$, $131.16,130.85,130.80,129.62,128.37(\mathrm{~d}, J=21.7 \mathrm{~Hz})$, 128.20, 128.00, 21.54. ${ }^{19} \mathrm{~F}$ NMR $\left(376 \mathrm{MHz}, \mathrm{CDCl}_{3}\right) \delta 66.47$. HRMS (ESI): $m / z$ calcd for $\mathrm{C}_{14} \mathrm{H}_{13} \mathrm{O}_{3} \mathrm{NFS}[\mathrm{M}+\mathrm{H}]^{+}$, 294.05947; found, 294.05960.

\section{Docking study}

The X-ray crystallographic structure of the adduct of the neutrophil elastase and benzene-1,2-disulfonyl fluoride (PDB Code: 6e69) was downloaded from the Protein Data Bank. The PDB protein and small molecule were prepared by adding hydrogen and missing residues in Accelrys Discovery Studio 2018 (Accelrys Software Inc., San Diego, CA) and converted to pdbqt format by Openbabel [31]. A grid box with dimensions of $40 \times 40 \times 40 \AA$ (-24.348, 1.759, 8.542 ) with a spacing of $0.375 \AA$ was constructed around the docking area using Autogrid 4.2 software. The docking was performed using Vina with exhaustiveness grade 8, with up to nine poses saved per molecule [32]. Accelrys Discovery Studio Client 2018 (Accelrys, San Diego, CA, USA) was used for interaction visualization, and the lowest energy conformation was selected. The ligand interactions with the neutrophil elastase was determined by PyMOL 0.99 and Accelrys Discovery Studio Client 2018 (Accelrys, San Diego, CA, USA).

\section{In vitro HNE inhibition studies [29]}

Assays were performed at $37^{\circ} \mathrm{C}$ in buffer $(200 \mathrm{mM} \mathrm{NaCl}$, $200 \mathrm{mM}$ Tris- $\mathrm{HCl}, \mathrm{pH}=7.5,0.01 \%$ BSA, 0.05\% Tween-20). The peptide substrate MeOsuc-AAPV-AFC (ab142178) and hNE enzyme (ab91099) were purchased from Abcam. Reactions were started by the addition of various inhibitors in $200 \mu \mathrm{L}$ of enzyme assay containing $1 \mathrm{mU}$ of hNE and $25 \mu \mathrm{M}$ peptide substrates. The fluorescence measurement was immediately performed with $E_{\mathrm{x}}=380 \mathrm{~nm}$ and $E_{\mathrm{m}}=460 \mathrm{~nm}$ for $10 \mathrm{~min}$ to calculate the kinetic changes of the fluorescence. The inhibition was calculated using Graphpad Prism. Sivelestat was used as the reference compound.

\section{Cell viability assay}

Human colon cancer cell HCT-116, human liver cancer cell HepG2, human gastric cancer cell BGC-823, human lung cancer cell A549, and human breast adenocarcinoma cell MCF-7 were obtained from cell center of Chinese Academy of Medical Sciences \& Peking Union Medical College. They were cultured in DMEM medium (Invitrogen) with $10 \%$ fetal bovine serum (Gibco) at $37{ }^{\circ} \mathrm{C}$ with $5 \% \mathrm{CO}_{2}$. All 
compounds were assessed the cyto-toxicity in five human cancer cell lines, namely HCT-116, HepG2, BGC-823, MCF-7, and A549 following the protocol of MTT (3-(4,5dimethylthiazol-2-yl)-2,5-diphenyltetrazolium bromide) cell proliferation assay [33, 34].

Acknowledgements This work was financially supported by The CAMS Innovation Fund for Medical Sciences (2017-I2M-1-010), The Drug Innovation Major Project (2018ZX09711001). This paper is dedicated to Prof. Robert Vince's 80th birthday.

\section{Compliance with ethical standards}

Conflict of interest The authors declare that they have no conflict of interest.

Publisher's note Springer Nature remains neutral with regard to jurisdictional claims in published maps and institutional affiliations.

\section{References}

1. Polak SB, Van Gool IC, Cohen D, von der Thusen JH, van Paassen J. A systematic review of pathological findings in COVID-19: a pathophysiological timeline and possible mechanisms of disease progression. Mod Pathol. 2020;33:2128-38.

2. Wu C, Chen X, Cai Y, Xia J, Zhou X, Xu S, Huang H, Zhang L, Zhou X, Du C, et al. Risk factors associated with acute respiratory distress syndrome and death in patients with coronavirus disease 2019 pneumonia in Wuhan, China. JAMA Intern Med. 2020;180:934-43.

3. Wilkinson TS, Conway Morris A, Kefala K, O'Kane CM, Moore NR, Booth NA, McAuley DF, Dhaliwal K, Walsh TS, Haslett C, et al. Ventilator-associated pneumonia is characterized by excessive release of neutrophil proteases in the lung. Chest. 2012;142:1425-32.

4. Butt Y, Kurdowska A, Allen TC. Acute lung injury: a clinical and molecular review. Arch Pathol Lab Med. 2016;140:345-50.

5. Nanchal RS, Truwit JD. Recent advances in understanding and treating acute respiratory distress syndrome. F1000Res. 2018;7:1322.

6. Crocetti L, Quinn MT, Schepetkin IA, Giovannoni MP. A patenting perspective on human neutrophil elastase (HNE) inhibitors (2014-2018) and their therapeutic applications. Expert Opin Ther Pat. 2019;29:555-78.

7. Lerman I, Hammes SR. Neutrophil elastase in the tumor microenvironment. Steroids. 2018;133:96-101.

8. Walker B, Lynas JF. Strategies for the inhibition of serine proteases. Cell Mol Life Sci. 2001;58:596-624.

9. Hedstrom L. Serine protease mechanism and specificity. Chem Rev. 2002;102:4501-24.

10. Chua F, Laurent GJ. Neutrophil elastase: mediator of extracellular matrix destruction and accumulation. Proc Am Thorac Soc. 2006;3:424-7.

11. Thulborn SJ, Mistry V, Brightling CE, Moffitt KL, Ribeiro D, Bafadhel M. Neutrophil elastase as a biomarker for bacterial infection in COPD. Respir Res. 2019;20:170.

12. Liou TG, Campbell EJ. Nonisotropic enzyme-inhibitor interactions: a novel nonoxidative mechanism for quantum proteolysis by human neutrophils. Biochemistry. 1995;34:16171-7.

13. Wang Z, Chen F, Zhai R, Zhang L, Su L, Lin X, Thompson T, Christiani DC. Plasma neutrophil elastase and elafin imbalance is associated with acute respiratory distress syndrome (ARDS) development. PLoS ONE. 2009;4:e4380.
14. Rubio F, Cooley J, Accurso FJ, Remold-O’Donnell E. Linkage of neutrophil serine proteases and decreased surfactant protein-A (SPA) levels in inflammatory lung disease. Thorax. 2004;59:318-23.

15. Fan E, Brodie D, Slutsky AS. Acute respiratory distress syndrome: advances in diagnosis and treatment. JAMA. 2018;319: 698-710.

16. Fischer BM, Voynow JA. Neutrophil elastase induces MUC5AC gene expression in airway epithelium via a pathway involving reactive oxygen species. Am J Respir Cell Mol Biol. 2002;26:447-52.

17. Mohamed MMA, El-Shimy IA, Hadi MA. Neutrophil elastase inhibitors: a potential prophylactic treatment option for SARSCoV-2-induced respiratory complications? Crit Care. 2020;24:311.

18. Lee WL, Downey GP. Leukocyte elastase: physiological functions and role in acute lung injury. Am J Respir Crit Care Med. 2001;164:896-904.

19. Siedle B, Hrenn A, Merfort I. Natural compounds as inhibitors of human neutrophil elastase. Planta Med. 2007;73:401-20.

20. Martins FT, Assis DM, Dos Santos MH, Camps I, Veloso MP, Juliano MA, Alves LC, Doriguetto AC. Natural polyprenylated benzophenones inhibiting cysteine and serine proteases. Eur $\mathrm{J}$ Med Chem. 2009;44:1230-9.

21. Kim JY, Wang Y, Uddin Z, Song YH, Li ZP, Jenis J, Park KH. Competitive neutrophil elastase inhibitory isoflavones from the roots of Flemingia philippinensis. Bioorg Chem. 2018;78:249-57.

22. Tebbutt SJ. Technology evaluation: transgenic alpha-1-antitrypsin (AAT), PPL therapeutics. Curr Opin Mol Ther. 2000;2:199-204.

23. Toda Y, Takahashi T, Maeshima K, Shimizu H, Inoue K, Morimatsu H, Omori E, Takeuchi M, Akagi R, Morita K. A neutrophil elastase inhibitor, sivelestat, ameliorates lung injury after hemorrhagic shock in rats. Int J Mol Med. 2007;19:237-43.

24. Iwata K, Doi A, Ohji G, Oka H, Oba Y, Takimoto K, Igarashi W, Gremillion DH, Shimada T. Effect of neutrophil elastase inhibitor (sivelestat sodium) in the treatment of acute lung injury (ALI) and acute respiratory distress syndrome (ARDS): a systematic review and meta-analysis. Intern Med. 2010;49:2423-32.

25. Aikawa N, Kawasaki Y. Clinical utility of the neutrophil elastase inhibitor sivelestat for the treatment of acute respiratory distress syndrome. Ther Clin Risk Manag. 2014;10:621-9.

26. Zeiher BG, Artigas A, Vincent JL, Dmitrienko A, Jackson K, Thompson BT, Bernard G, Group SS. Neutrophil elastase inhibition in acute lung injury: results of the STRIVE study. Crit Care Med. 2004;32:1695-702.

27. Vogelmeier C, Aquino TO, O'Brien CD, Perrett J, Gunawardena KA. A randomised, placebo-controlled, dose-finding study of AZD9668, an oral inhibitor of neutrophil elastase, in patients with chronic obstructive pulmonary disease treated with tiotropium. COPD. 2012;9:111-20.

28. Stockley R, De Soyza A, Gunawardena K, Perrett J, ForsmanSemb K, Entwistle N, Snell N. Phase II study of a neutrophil elastase inhibitor (AZD9668) in patients with bronchiectasis. Respir Med. 2013;107:524-33.

29. von Nussbaum F, Li VM, Allerheiligen S, Anlauf S, Barfacker L, Bechem M, Delbeck M, Fitzgerald MF, Gerisch M, GielenHaertwig $\mathrm{H}$, et al. Freezing the bioactive conformation to boost potency: the identification of BAY 85-8501, a selective and potent inhibitor of human neutrophil elastase for pulmonary diseases. ChemMedChem. 2015;10:1163-73.

30. Zheng Q, Woehl JL, Kitamura S, Santos-Martins D, Smedley CJ, Li G, Forli S, Moses JE, Wolan DW, Sharpless KB. SuFExenabled, agnostic discovery of covalent inhibitors of human neutrophil elastase. Proc Natl Acad Sci USA. 2019;116: 18808-14.

31. O'Boyle N, Banck M, James C, Morley C, Vandermeersch T, Hutchison G. Open Babel: an open chemical toolbox. J Cheminform. 2011;3:33 
32. Trott O, Olson AJ. AutoDock Vina: improving the speed and accuracy of docking with a new scoring function, efficient optimization, and multithreading. J Comput Chem. 2010;31: 455-61.

33. Wen H, Liu Y, Wang S, Wang T, Zhang G, Chen X, Li Y, Cui H, Lai F, Sheng L. Design and synthesis of indoleamine 2,3- dioxygenase 1 inhibitors and evaluation of their use as anti-tumor agents. Molecules. 2019;24:2124.

34. Wen H, Xue N, Wu F, He Y, Zhang G, Hu Z, Cui H. Exploration of the fluorescent properties and the modulated activities against sirtuin fluorogenic assays of chromenone-derived natural products. Molecules. 2018;23:1063. 